Marija Živanović ${ }^{1}$

City Kragujevac, Kragujevac

Nada Živanović, PhD. ${ }^{2}$

University „Union” Beograd,

Faculty for business industrial management, Belgrade
SCIENTIFIC REVIEW ARTICLE

Received: November 24, 2015

Accepted: January 29, 2015

\title{
BUSINESS PROCESS IMPROVEMENT APPLICATION OF MODERN MANAGEMENT TECHNIQUES
}

\begin{abstract}
Today, globally operating business world is exposed to constant change processes. Reengineering is the driving force that helps companies, business and manufacturing organizations to achieve success in the new millennium that is full of challenges, risks, information explosion, Internet communications, teleconferencing and global competition. Therefore, effective business strategy, well-trained management personnel, financial - tech resources (IT), management skills and the skills and flexibility (responsiveness) are essential for success in business. Market conditions will be created by people who will decide on the changes, plans and projects, organizational culture, new challenges to create value that can be sold (goods and services) and how to define where consumers expect to buy. In this paper, attention is concentrated on the three most important methods and techniques for strategic business changes, observed through the application re-engineering, including self-assessment, teamwork and benchmarking.
\end{abstract}

Keywords: business processes, reengineering, benchmarking, teamwork

JEL classification: D01, L21, M20

\section{ПОБОЉШАЊЕ ПОСЛОВНИХ ПРОЦЕСА ПРИМЕНОМ САВРЕМЕНИХ ТЕХНИКА ПОСЛОВАЊА}

\section{Абстракт}

Данас, на глобалном нивоу пословања, пословни свет је изложен сталним проиесима промена. Реинженеринг као покретачка снага помаже компанијама, пословним и производним организачијама да остваре успех у окружеюу које је пуно изазова, ризика, експлозије информаиија као u глобалне конкуренције. Ефикасне пословне старегије, добро обучен менацерски кадар, финансијско - технолошки ресурси (ИТ), менацерска знања и вештине и флексибилност (брзина реаговања) су неопходни за успех у пословању предузећа. Услове на тржишту стварају ьуди који ће одлучивати о променама, плановима и пројектима, организационој култури, новим изазовима о начину како да стварају вредност коју могу да продају (производе и услуге) и како да дефинишу место где потрошачи исте очекују

\footnotetext{
${ }^{1}$ marijazivanovickg@yahoo.com

2 profesorkanada@yahoo.com
} 
да купе. У раду се пажња усредсређује на три веома значајне методе и технике за стратегијске промене пословања, посматрано кроз примену реинжењеринга, и то: самооценивање, тимски рад и бенчмаркинг.

Кључне речи: пословни прочеси, реинженеринг, бенчмаркинг, тимски рад

\section{Introduction}

Strategic orientation of management for continuously improving the quality of business should be focused on improving the characteristics of existing manufacturing and business processes, and with as little investment funds, than would be the case for investing in the development of a completely new system. Application of modern technology can contribute to the management to operate more efficiently and better. When defining re-engineering in the world and our happiness are a number of definitions. It can be said that: Reengineering is a fundamental consideration and radical redesign of manufacturing systems, business processes, work and organization, taking 'dramatic' improvement of business performance in measuring critical points such as price, quality, service, speed. It is now widely accepted synonym for a new technological revolution that is taking place under the influence of information technology, focused on the transformation of the existing production.

The main objective of re-engineering the production and business management systems to reduce the cost of production, products, services, improve quality, increase the range and volume of production, increase business efficiency, increase speed of operation, accuracy, increase competitiveness and so on. This is achieved through the management first perform a partial improvement and rationalization of existing technologies and technological processes. If you do not ensure satisfactorily and expected results, introducing new technologies, and if these new technologies do not contribute sufficiently to improving the market position of the production system, access to fundamental, radical, even 'dramatic' changes and the implementation and development of the re-engineering of production and business processes. In doing so, we should not only rely on own resources but should also count on additional investment. If the analysis shows that the need to access the application of this technique, it should be implemented vigorously, comprehensively and without fear, because then the results would be adequate to the organization in which he carried out, i.e. the internal environment, and for its external - the external environment (customers, shareholders, business partners and other stakeholders).

It is important to warn you that the management in an effort to make the implementation of these techniques in the existing manufacturing and business systems should be required to examine the current and future productivity, expressed in commodity and value-form, before making any decision.

From the aspect of improving the quality of management, industrial companies and meeting strategic objectives with the strategic intent to the selection of such changes, new techniques help to the benefit of the success of management, think beyond.

\section{Strategy business self-assessment}

Self-assessment (self-assessment) is the process that organizations should implement in order to determine its position on the market or assessment or determine the significance, importance and value of their own organization. This technique is successful if it is implemented in terms of training of personnel, their impartiality and 
the criteria that will be applied. Therefore, it is necessary to have experts, who will be constantly trained, compare their criteria with other colleagues in the industry, which will create and implement their questionnaires and others.

The world today has developed questionnaires at the national level, according to certain schemes. The results and evaluation are the starting point for taking corrective and preventive actions by management. (Zakić, 2009) The some companies require their organizational units to conduct a self-assessment on an annual basis according to standardized internal documents and models (procedures and established eligibility criteria). As a rule, self-assessment provides for the functions of leadership, strategic planning, refer to the customer users, human resources, process management, management of technology, environmental management, information management and business results achieved as a significant category in reward quality. Consequently, we can say that: (Loveday, 1998, p. 64-66).

- Self-assessment is an important tool to measure and evaluate business performance across the company in relation to a number of criteria to be met when applying for quality awards (Japanese, American, European or our Award 'Oskar quality') and,

- Self-assessment is used for verification, which means teams limit the feasibility of the desired results of operations for process improvement. These checks companies use as the basis for comprehensive and effective comparisons within the benchmarks and as the basis for improving the performance of the business process.

If a company wants to set itself apart by its high-quality products and services in today's competitive market, it must be able to set goals to improve and to measure their progress. People have a certain fear of the implementation process of self-assessment, but all you have to do it is to make a simple plan of action that sets small realistic goals within the domain of critical success factors, defined from top to bottom of the ladder. This may include in addition to the goals of staff development and improvement of work processes. Measuring their own progress shows how well you perform set tasks and goals. (Carr, 1995) Based on the international experience it is believed that companies need to shift from an annual assessment of the structure that makes possible continuous measurement of its own progress. Problem applying techniques of self-assessment is in setting goals and in measuring. Goals should be simple, easy to understand and interesting enough for people to which they relate in order to force them to take action to meet this objective. Self-assessment will help people to understand the spirit of policy changes in the business organization. Knowledge of strategies and objectives as the basis of the corporate will help to set targets, new techniques and the quality of business processes, to explain the vision of the organization and what it is that top management wants to achieve. Teams and individuals need that provided the opportunities to developing own goals and to measure own progress. Practice and science have shown that short-term goals can quickly lead to success and to motivate people to set new challenging goals for future self-assessment. On a business example of a company that had mapped out a strategic goal, says that top management had: high awareness of quality processes to be redesigned and goals-oriented customers. (Babcock, 2010) The next step was related to the transfer of these objectives at lower levels, and teams should participate in the research and knowledge: who are the customers, which way to establish communication with customers, how to get feedback and how to measure customer satisfaction achieved. 


\section{Benchmarking process}

Benchmarking is a technique applied to modeling and improving business processes in developed companies in the world that can bring high business results in the application of technology re-engineering of business processes, which are now also very widely used in practice in order to improve productivity and achieve competitive advantage. It starts from the fact that the re-engineering of production or business begins by establishing a model of the real world and that in these cases one of the possible ways to improve the operations that are going to become familiar with 'best practice' that exists in a particular activity at that time. The key role of this technique in the re-engineering is to enable the company to come up with creative solutions to redesign their processes and to achieve a high quality improvement of its processes and quality performance of products and services.

Benchmarking means the process by which we measure their results with others and learn from others, usually direct competitors. Ranges with comparing the strategies of competitors with their own strategy, continues comparing the most important business processes, products, technical solutions and features competitors with their own solutions and functions in order to come to know the actual gaps and evaluate opportunities to become better than others. (Ličina, 2012, p. 196)

Of particular importance for companies to constantly adjust the goals, activities and organization changes that occur at the customer. This process of adaptation can be achieved by continuous comparison of products; services and concrete practice their own companies with the strongest competitor, or with companies that are considered leaders in this type of activity, the use of relative measures. (Doumeingts, 1997)

Benchmarking or improvement comparing represents managerial tool that serves to define the changes accomplished goals. Represents a continuous assessment of business objectives and comparisons with 'best in class' or realized and accepted standard, based on measurable characteristics. It aimed at maintaining or establishing a competitive advantage. The main aims of the application in companies that are based on the experiences of leaders set reference points and then use them to achieve the same or better performance.

Benchmarking method applies to a large extent modern management, because of its simplicity and the characteristic of positive characteristics. Advantages of benchmarking are collecting strategic, managerial, and organizational and other so-called 'hard' data that can be compared, and whose data comes from real life, that is, the practice of the best companies in industry. (Deming, 1993).

Management is particularly important task before implementing the decision on the application re-engineering using the method of benchmarking to understand the essence of the technique. In fact, you should know that the benchmarking technique is reflected in the activities of defining, analyzing and measuring their own processes. This method can reveal problems and weaknesses in their own organization. Practice shows that benchmarking should be seen as the final step is taken only when companies implement all the necessary changes and improvements and execute when measuring the results achieved by introducing these improvements. The realized value of the process depends on the results of work teams. Each task force is focused on business process. Benchmarking and teams are techniques that need to be jointly used to improve the performance of the business process and the entire organization.

Key phases of the benchmarking process are:

1. Detailed analysis of the business process;

2. Measuring the adequacy of carrying out this process in their own organization; 
3. Compare the ways in which this technique is implemented and the achieved level of its implementation in relation to its competitors, that is, companies with the best pragmatic experiences within their own company or companies 'world-class';

4. Improving your own processes and business performance to the level of 'world-class'.

Benchmarking procedure includes the following steps:

- Systematization objectives of benchmarking;

- Identification of relevant facilities to be improved in accordance with the standard;

- Applicability of the current practice of benchmarking;

- Finding typical, illustrated examples that will serve as a standard for comparison;

- $\quad$ Examine potential problems and future research directions.

Experiences of developed companies indicated that the paradox in benchmarking lies in the fact that it is difficult to become 'the best' by copying others, also the best business entity. In fact, just copy the best practices of other companies is not enough. It is necessary to fully understand the process of its own, in order to create safety in terms of which one of them will reach the limit so important. If this is not understood correctly, all of the implementation of reengineering efforts may be in vain. A key step in achieving a successful outcome is to determine: What business processes should be comparable benchmarking? (Dragomanović,1998). The first step is to create a 'process model' of business, that show what the organization does and how it looks. When the processes of study and accept the impression that the organization does two things: Creates and develops something that makes and sells; and makes and sells something that is created and developed. When an organization makes a model of the process and understand how the processes are in operation, can initiate simplification and elimination of redundancies (engineering business processes). (Janićijević, 2008).

However, the management of the operation is required the ability to allocate priorities i.e. key processes for competitiveness. Another priority of the process model is to determine the process owner, or the owner of a set of benchmarks benchmarking, which will be responsible for their implementation.

\section{What process should be benchmarked}

When you define the model and introduce business processes, organizations need to find the most convenient way to choose where to start the implementation of benchmarking as an important technique in business process reengineering. Therefore, it is necessary to create a clear picture of the business objectives and understand the market in which the company is located, in terms of customer demands and competitive pressures. The best starting point for this is to define for each product or service that you offer the customer the criteria for qualifying orders and receiving orders that are quickly becoming industry standards. However, that company got the job, i.e. satisfy the customer needs to create a diversity that the buyer will be seen as an additional expense, over those offered by the competition. (Klarin, 1996) It is the criterion of obtaining orders for business, which are in fact the performance of the company must achieve in a market. 
It is important to add another aspect of this model. The fact is that over time, changing customer expectations and competitive opportunities, and what today brings business can become a qualification for tomorrow or today's model criteria receiving the order will become tomorrow's qualifying orders. In addition to these requirements should be included so 'critical success factors' relating to the organization internally to the organization meet the external needs in focus. The key success factor is the need for an environment that encourages innovation and the need for effective teamwork. (Živanovic, N., Živanovic, V., Todorova, \& D., Živanovic, M. (2013).

The most successful performance benchmarking is when companies can see what they do in a whole new light and use the results to identify the source of benchmarking. Sources occur through developing a clear picture of the business as a set of processes that enable the actual activities that can increase competitiveness or to expose the main causes of the lack of competitiveness.

As defined processes for benchmarking helps to achieve competitive advantage, is a question that needs an answer to that company's management. On the basis of efficiency in modeling, business processes are increasing efficiency benchmarking. In fact, the efficiency can be achieved so that the established critical factors and associated processes contribute to the definition of performance that connects business goals within the organization. Regulated processes can be measured, which allows all parts of the enterprise to measure their own performance against the objectives of the business performance. Effective measures contribute to monitoring the development of improvement activities within the company at any time in relation to the needs of business in a reasonable manner, and not in relation to what individual departments may wish. An example of an industrial company illustrates how processes help identify benchmarking? According to the data, the company is having difficulty in the redistribution of daily operations at the plant. The initial step in solving emerging problems was to study the best practices to control plant and systems deployment. After the modeling process, it was determined that the problem lies in the management order.

When they get orders from customers to production, which normally delayed by two to three weeks, it meant that everything will have to be redeployed to the more shortened deadlines. Practice shows that the competitive advantage of innovative technology driven processes much more difficult to copy than the one driven by the product, especially when it is to be achieved for the first time in the company, which would later use the other.

\section{Main features benchmarking in process reengineering}

In the business world, our companies need to know a few important characteristics in comparison with the best in the market, namely: (Khan, 2004).

1) For the application of benchmarking as an important technique to improve processes and overall organizational performance in the market it is important to question the type of benchmarking. It is considered in two cases: First, consider the internal benchmarking to be carried out within the company. Analyzed similar trends work in different departments (regions), and therefore their values are compared with each other. Advantages of this type are:

- Rapid rise and the organization's performance,

- Efficient collection of information and the number of data,

- Application in medium and large companies, sometimes in small businesses.

Second, consider the benchmarking relating to competition in the industry: The point is to identify and compare the strong and weak points of direct competition. This strategy differs from the classical analysis of competition. The advantages are: 
- Manufacturing and business processes that are compared directly which facilitates fast transfer,

- Clear own position against the competition.

\section{Bench marketing how it's done}

Way as to ensure the successful implementation of benchmarking in the implementation and development of reengineering is as follows:

1. The objectives in doing so, we have in mind:

- Net position in the market. The key question is: What effect enterprise customers the highest prices? Is it necessary and is it possible to compare the production? The key question is: Where are our problems? Where deficits arise?

- Performgoals. For example, shorten delivery time. Developalistofpriorities. Establish Benchmarking procedure: define what we want to subject benchmarking (procedure, process, product, strategy). Define how to most effectively implement benchmarking (internally, in relation to the competition, functional) and establish benchmarking, project team assigned responsibilities and tasks.

2. Implemented internal analysis

- Conducts analysis to set benchmarks in the areas of internal and production processes. Defines who is doing what, how, and why, at what time and with what results?

- Defines the market to which it refers benchmarking. Define the measured variables (egg. Determining production costs per unit, share of F \& E (cost of sales, reclamation and quota stocks on hand).

- Develop a catalog of questions that serve as a basis for comparison with the benchmarking partner.

3. Implemented comparison

- Choosing the right partner. Define which companies in the industry that have the desired competence? Determine whether you can get under the circumstances the anonymous data from those companies that are the best in practice?

- Developed a catalog of questions compared with the benchmarking partner.

- Data benchmarking partners realize preferably as pre-testing.

- Compare these data with the data from our company. Analyze the causes of declining results. Determine whether you can exclude measurement errors. Determine whether the processes that are being compared are identical. Determine whether there is a real deficit own power. (Živanović, N., \& Lukić, S. 2009, p. 142).

4. Measures to improve. Measures to improve it are necessary to determine the specific deficit of power, the goals of their own company and determine priorities necessary:

- Make plan of action, what you need, what you can and assess the situation 
according to the introduced changes? (It is important to know that when you do not need to copy the best practical methods of benchmark partners, but should be optimized and do not carry the product has passed the target).

- Identify the tasks and responsibilities: who, what and when to do it?

- Define boundaries to time quickly noticed success in trade.

5. Transfer and control of benchmarking Re-examine the application of measures to determine:

- $\quad$ Are the boundaries established and whether they meet the goals?

- Is the increased success?

- Are the improvements cost?

- Furthermore, introduce further measures related to the development and qualification.

After the implementation of measures to improve the techniques in the context of benchmarking (comparing to the market), the results should once again compare with a partner. In doing so, to determine:

- Can the results really transferred, i.e. 'Transferred' to the business partner with whom the comparisons?

- $\quad$ Subject to further work needs to initiate a new benchmarking project with a new partner.

- $\quad$ Plan long term goal: It means continuous improvement process with the help of benchmarking.

\section{The Importance of Teams in Process Reengineering}

Teams are the driving force in the business of any organization. To improve any process or operation in this technique, it is necessary to include a team of experts of different professional. For high efficiency of the team, it is essential that the team is motivated, trained, and that his clear goal, that is creative and innovative and has provided funds for the work. Capable team may lead the company to a high position of competitiveness (Aston,1998, p. 62-65). The meaning of the teams is the participation of employees in achieving continuous process improvement process re-engineering, in order to achieve organizational efficiency. Teamwork is the means by which the company becomes better in the market, achieves faster customer requirements and implements secure business applications. That is exactly what the competition wants to reach. (Collins, 1994).

\section{The Role of Team in the Implementation process Reengineering}

Given the fact that success in business enterprise creates the principle of teamwork and proper cooperation of employees who encourage and accelerate the achievement of that success, every manager knows that after the missions and goals of the business, you need to determine and evaluate the level of cooperation and teamwork in a group. This is necessary to achieve the desired results and the plan set. If people are not working together to solve tasks, especially for complex structures activities reengineering 
process, it may appear different problems that lead to the problem of achieving success in carrying out tasks of individuals. (Towers, S. 1996.) This leads to poor communication, inefficient labor, poor customer service, increased operating costs, low productivity, poor quality products and services, and poor overall performance of the company. Teamwork is a type of group work in which members have their clear responsibilities, scope of work and responsibilities, agreed by working with other team members and contributing to the achievement of set objectives.

\section{How to Remove Bad Factors that Hinder Teamwork in the Reengineering}

The task manager is to remove all obstacles that stand in the way of success, and which in practice occur due to:

1. Lack of common goals of teamwork and cooperation;

2. Created conflict among people of different opinions about the process of reengineering;

3. Unsolved problems in achieving success;

4. Unclear roles of employees and their duties and responsibilities;

5. Individual plans, conflicts and struggles for prestige, and competition among employees;

6. Unequal reward for the success of individuals;

7. Dissolution of good communication;

8. Bad planning;

9. Lack of desire and mood for giving initiatives for teamwork;

10. Lack of resources needed for the success of the team and others.

\section{Conclusion}

Industrial companies today, at home and abroad, are largely dependent on foreign knowledge and pragmatic application of the doctrine of know-how. Development and application of modern techniques, methods and technologies that increase market share and product quality, it is imperative to today's management. For the implementation of the above methods are needed to improve the business strategic management decisions. These methods of self-assessment, teamwork and benchmarking with the application process reengineering, enabling the planning and implementation of strategies to improve the operation of industrial enterprises. The implementation of these methods contribute to: improving the quality of business processes, achieving the necessary bandwidth of continuous improvement, efficiency and economy of operations and continuous monitoring of the work of the best companies in the class. This makes it possible to incorporate a wide range of modern knowledge which is constructed a large number of optimal solutions as the essence of strategic intentions, choices and target companies. Management by efficiently creating the space needed to quickly and efficiently penetrate with its strategy of producing products on the market and thus create a brand as a basis for competition. Reengineering is an effective technique in recent years has been rising and implemented in a large number of modern industrial enterprises. The strategic objective of this technique should be a priority management, in order to quickly generate their planning and strategic solutions. 
Generating the best knowledge planners, designers, and strategic management through modern solutions, increases the level of flexibility, achieves greater motivation of employees and implement a continuous monitoring of performance achieved selfassessment. Modern business, economic conditions incorporated in the factors of product quality and service, are placed in the foreground. That said, it's basically all companies, it is important to achieve the goal of such a way to achieve efficiency. Accordance with the functional and performance benchmarking applied in practice companies, within the context of modern business, both evolutionary and internal benchmarking exercise to determine the level of the key parameters of benchmarking as a development and modern business processes.

\section{References}

Aston, C. (1998), The team that brought millions of dollars, Compendium quality, Europe Jugoinspekt, no. 9-10, Belgrade, pp. 62-65

Babcock, D. (2010), “Management Strategies for the Cloud Revolution”, Mc GrawHill, New York

Carr, D. (1995), Best Practices in Reengineering, MC Graw Hill, Inc., New York etc.

Collins, E. (1994), Taking hold of change, Harvard Business Review

Deming, E. (1993), Out of the Crisis, Cambridge, MA: MIT Press

Doumeingts, G. (1997), Modeling Techniques for Business Process -RE Engineering and Benchmarking. Chapman \& Hall. United Kingdom

Dragomanović, N. (1998), Re-engineering business processes, quality. Business policy. Belgrade

Janićijević, N. (2008), Organizational Behavior , Datastaus, Belgrade

Khan R.N., (2004), Business Process Management: A Practical Guide, Tampa: Meghan -Kiffer press,

Klarin, M. (1996), Organization and planning of production processes, MF Belgrade,

Ličina, M. (2012), Benchmarking in procurement. Ekonomika, 58(2), 196

Loveday, M. (1998), The applicable definitions, Compendium quality, 6-7, 64-66, Europe Jugoinspekt. Belgrade

Towers, S. (1996), Business Reengineering, Stanly Thomas Ltd. 1996, p 48

Zakić, N. (2009), Innovation and business process management, Foundation Andrejevic, Belgrade

Živanović, N., Lukić, S. (2009), Reengineering, Pan-European University “ APEIRON “ Banja Luka, Bosnia and Herzegovina / RS, p.142.

Živanovic, N., Živanovic, V., Todorova, \& D., Živanovic, M. (2013), Management of products of work in a function of efficient techniques, FBIM Transactions, 1(1), 66-73. 